\title{
Summer Habitat Preferences ANd ACtivity PATterns OF River OtTERs IN Grand Teton NATIONAL PARK
}

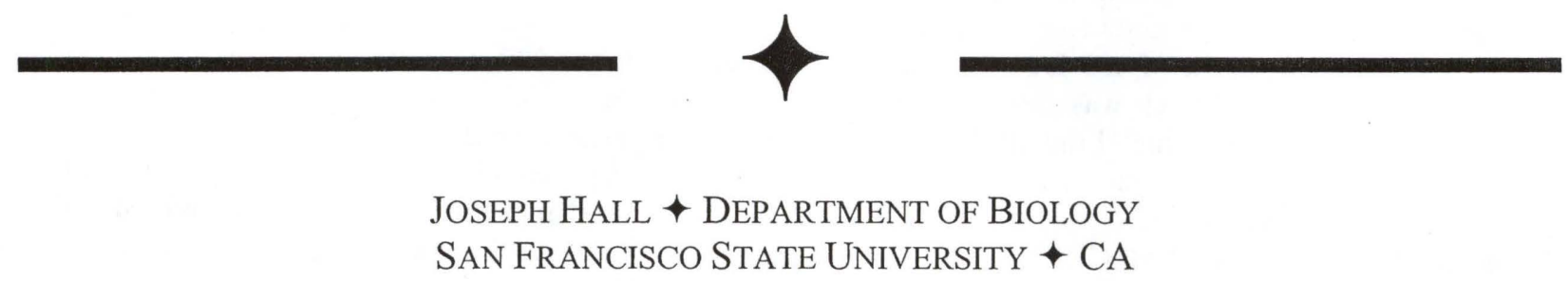

\begin{abstract}
$\uparrow \quad$ ABSTRACT
I studied the natural history of river otters (Lontra canadensis) during the summers of 19821986 and 1995-1997 in Grand Teton National Park, Wyoming. Habitat preferences were analyzed by tallying sightings on 5 types of habitat along $16 \mathrm{~km}$ of the Snake River. Otters were seen on all 5 habitat types and exhibited a strong preference for the $\operatorname{logjam} /$ beaver lodge category. Beavers and otters sometimes occupied a lodge simultaneously.
\end{abstract}

I recorded daytime activity directly in 1982 and noted a large peak in mid-morning and a small one in late afternoon. To obtain information indirectly on round-the-clock activity I employed 6 modified camera monitors activated by treadle-switches at frequently used sites. Pooled records for 3 summers showed almost two and a half times higher activity by day than by night, a finding opposite of what was expected. The hypothesis I suggest is that diurnal activity exceeds nocturnal activity because of the habituation of otters to humans over a half century's tradition of frequent exposure and non-harassment in the national park.

In the summers of 1982-1986 and 19951997 I made a study of the natural history of river otters (Lontra canadensis), in Grand Teton National Park under auspices of the University of Wyoming National Park Service Research Center. Occasional observations were made along the Snake River from Flagg Ranch near the north boundary of the park to the north end of Jackson Lake and from Pacific Creek to Deadman's Bar. However, the $3 \mathrm{~km}$ stretch of river from just below Jackson Lake Dam to the Oxbow was the site of most intensive study. (See Fig. 1)

\section{$\uparrow \quad$ MeTHODS}

\section{Habitat Preference}

In analyzing the habitat preference aspect of natural history, the first step was to choose a site for documenting variety and extent of riverside habitats. The $16 \mathrm{~km}$ section of the river from Pacific Creek to Deadman's Bar was chosen because it had ample habitat variety and because it was regularly traversed by guided float trips. Common woody plants along this stretch of the river at a mean elevation of $2040 \mathrm{~m}$ are willows (Salix sp.), quaking aspen (Populus tremuloides), narrow leaf cottonwood (Populus angustifolia), lodgepole pine (Pinus contorta), Douglas-fir (Pseudotsuga menziesii), blue spruce (Picea pungens), Engelmann spruce (Picea engelmannii), and big sagebrush (Artemisia tridentata).

I prepared a master map of the extent of 5 habitat categories largely based on a recent series of infra-red aerial photographs at the Research Center. As expected, the preliminary overlay map needed some fine tuning by checking habitats on the ground and by canoe. 
I was fortunate in persuading some boatmen of the 3 commercial float tour companies to record on a field map sites where otters were seen on daily tours. I collected these maps every few days, matched sightings to habitat types, and entered the data on a master tally.

\section{Activity Pattern}

Direct observations in the field supplied information on patterns of diurnal activity. Indirect observations, by means of camera monitors described below, allowed me to compare night-time and daytime activity. I used 6 Vivitar PS50 Date-a-print, Auto Flash $35 \mathrm{~mm}$ cameras. Each was fitted into a plywood cradle on the back of which I mounted a 12volt solenoid powered by $8 \mathrm{C}$-cell batteries. A $15 \times 33$ $\mathrm{cm}$ pressure-sensitive treadle switch made of $2 \mathrm{ABS}$ plastic sheets was connected to the $8 \mathrm{C}$-cells by about $6 \mathrm{~m}$ of wire. When an otter stepped onto the buried treadle switch the solenoid's plunger was pulled down into its well. This motion caused a small wooden lever to depress the camera's shutter release button and take a picture. A plywood "umbrella" was placed on top of the monitor to protect it from rain or dew. The monitor itself was mounted on a small tripod or clamped to the trunk of a tree and aimed at the buried treadle switch about 4 or $5 \mathrm{~m}$ away.

I placed monitors at sites where otters were observed resting, feeding, traveling from one site to another, or using as latrines.

The 1995, 1996, and 1997 seasons were devoted largely to maintenance and repositioning the monitors. Each was checked every day or 2 for battery condition and general performance. I spent the remaining field time observing otter behavior.

\section{$\downarrow \quad$ RESUltS}

\section{Habitat Preference}

To compare preferences among the 5 habitats, it is helpful to adjust the raw units of use (67 sightings) to compensate for the wide spread of availability among habitats. (See Fig. 2). The simple ratio of sightings to $\mathrm{km}$ of habitat is used to obtain the preference index values shown in Fig. 3. For example, the Logjam/Beaver lodge preference index value of 32.5 is obtained by dividing 13 sightings by $0.4 \mathrm{~km}$ of available habitat. By contrast, the Gravel habitat with 20 sightings earned a Preference Index value of only 1.2 due to its much larger availability of almost $17 \mathrm{~km}$. The Preference Index values are best viewed as measures of density of use.

\section{Activity Pattern}

As shown in Fig. 4, the 56 daytime sightings had a bimodal distribution. There was a strong period of activity in the morning, followed by a midafternoon lull. A second, weaker peak occurred in the early evening.

The pooled total effort using camera monitors was 4,600 camera hours that yielded 34 otter recordings. This ratio of well over 100 camera hours per otter record indicates this technique has low efficiency. However, the noteworthy feature of the results is that there were 24 daytime records to only 10 by night. In addition to otters, monitors registered 2 bird species, 4 mammal species, and 6 canoeists and fishermen.

\section{DISCUSSION}

\section{Habitat Preference}

The most dramatic relationship documented in Fig. 3 is the strong preference otters show for Log jam/Beaver lodge (LL) habitat. Although this habitat had lowest availability ( $1 \%$ of the total $32 \mathrm{~km}$ ), LL was used approximately 9 times as intensively as grassy and coniferous habitats which tied for second choice. The close affinity between otters and Logjam/Beaver lodge habitats has been noted by various authors (Melquist and Hornocker 1983; Melquist and Dronkert 1987; Newman and Griffin 1994; Park 1971; Dubuc, and Krohn and Owen 1990; Choromanski and Fritzell 1982; Lariviere and Walton 1998). The advantageous features of this habitat usually mentioned are foraging areas and shelter for both otters and their prey, den sites, and low levels of human disturbance. In this study, otters were frequently noted feeding, wrestling, scent marking, and resting on top of lodges and on nearby, partly submerged logs.

On July 22, 1995 I monitored an active beaver lodge on the south bank of the Snake River from $0620 \mathrm{hr}$. to $2045 \mathrm{hr}$. The most notable observation was a 4-otter family and a 3-otter family simultaneously occupying the lodge for 4 hours. At least 1 or 2 beaver were also in the lodge for part of that period. Melquist and Hornocker (1983) noted 3 instances of joint occupancy. Prior to this 14 hour 
vigil I had not realized how intense the relationship between otters and beavers could be. It seems to lie on the boundary between commensalism and parasitism.

\section{Activity Pattern}

Because most observers describe otters as primarily nocturnal (Christensen 1984; Lariviere and Walton 1998; Melquist and Hornocker 1983; Melquist and Dronkert 1987), the monitor cameras' records of 24 diurnal to 10 nocturnal passages came as a surprise. I propose a "habituation hypothesis" to reconcile the paradox.

The hypothesis rests on the premise that otters are considerably more efficient in pursuit of underwater prey by day than by night. It is not difficult to accept this premise when we recognize how strongly otters must rely on vision in this pursuit. Another point to consider, however, is that human interference or harassment is virtually nonexistent after dark. The balance between these 2 opposing features of natural history presumably dictates whether an otter chooses to be active primarily by day or by night. The learned behavior of habituation is established generation by generation.

The past half century of protection of the otters in Grand Teton National Park from trapping and other kinds of harassment, has encouraged them to become significantly habituated to humans. My own observations in the $3 \mathrm{~km}$ of river between Jackson Lake Dam and the Oxbow strongly support this suggestion (See Fig. 5). A habituated otter need spend much less energy than a non-habituated animal in avoiding human contact. This, in my view, is the main disadvantage in being diurnal. Habituation allows otters to spend more time taking advantage of the chief asset of diurnal activity, which probably is the ease in capture of prey. I suggest, therefore, that habituation to humans wading in the shallows or floating by in boats has been strong enough to "tip the balance" in favor of more diurnal activity by lowering its energetic price. The observation of Melquist and Dronkert (1987) that diurnal activity of otters is not uncommon in undisturbed areas supports this hypothesis.

\section{ACKNOWLEDGEMENTS}

This research was partially supported by the University of Wyoming-National Park Service Research Center which also provided housing and lab space. K.L. Diem, former Director of the Research Center, and H.J. Harlow, current Director, advised me on field techniques and logistics and extended many courtesies.

The documentations of otter activity sites by boatmen of Triangle-X Float Trips, Barker-Ewing Float Trips and Jackson Lake Lodge Float Trips were greatly appreciated. J. Gilmore, E.A. Hall, L.H. Kearsley, P.M. Link, K.A. McGinley, and R.G. Richardson assisted in the field. P. Mui assisted in the field and on many other project activities. L. LaWhite designed an improved circuit for the monitor. D.E. Hall prepared figures 2, 3, \& 4. M.J.C. Kearsley and 2 anonymous reviewers read an earlier version of the manuscript. M.D. McCarty did an admirable job transcribing the manuscript.

To all these contributors I extend my sincere thanks.

\section{LITERATURE Cited}

Choromanski, J. F., and E. K. Fritzell. 1982. Status of the River Otter (Lutra canadensis) in Missouri. Transactions, Missouri Academy of Science 16:43-48.

Christensen, K. M. 1984. Habitat selection, food habits, and activity patterns of river otters in central Arizona (thesis). Flagstaff, AZ: Northern Arizona University. 72 p.

Dubuc, L. J., W. B. Krohn, a nd R. B. Owen. 1990. Predicting occurrence of river otters by habitat on Mount Desert Island, Maine. Journal of Wildlife Management 54(4):594 599.

Lariviere, S., and L. R. Walton. 1998. Lontra canadensis. Mammalian Species. 587:1 - 8.

Melquist, W. E., and M. G. Hornocker. 1983. Ecology of river otters in west central Idaho. Wildlife Monographs 83:1 - 60 .

Melquist, W. E., and A. E. Dronkert. 1987. River otter. In: Novak M, Baker JA, Obbard ME, Malloch B, editors. Wild furbearer management and conservation in North A merica. Ontario Ministry of Natural Resources, Toronto. p. 627 - 641. 
Newman, D. G., and C. R. Griffin. 1994. Wetland use by river otters in Massachusetts. Journal of Wildlife Management 58(1):18 - 23.

Park, E. 1971. The w orld of the otter. Philadelphia: JB Lippincott Company. 159 p. 


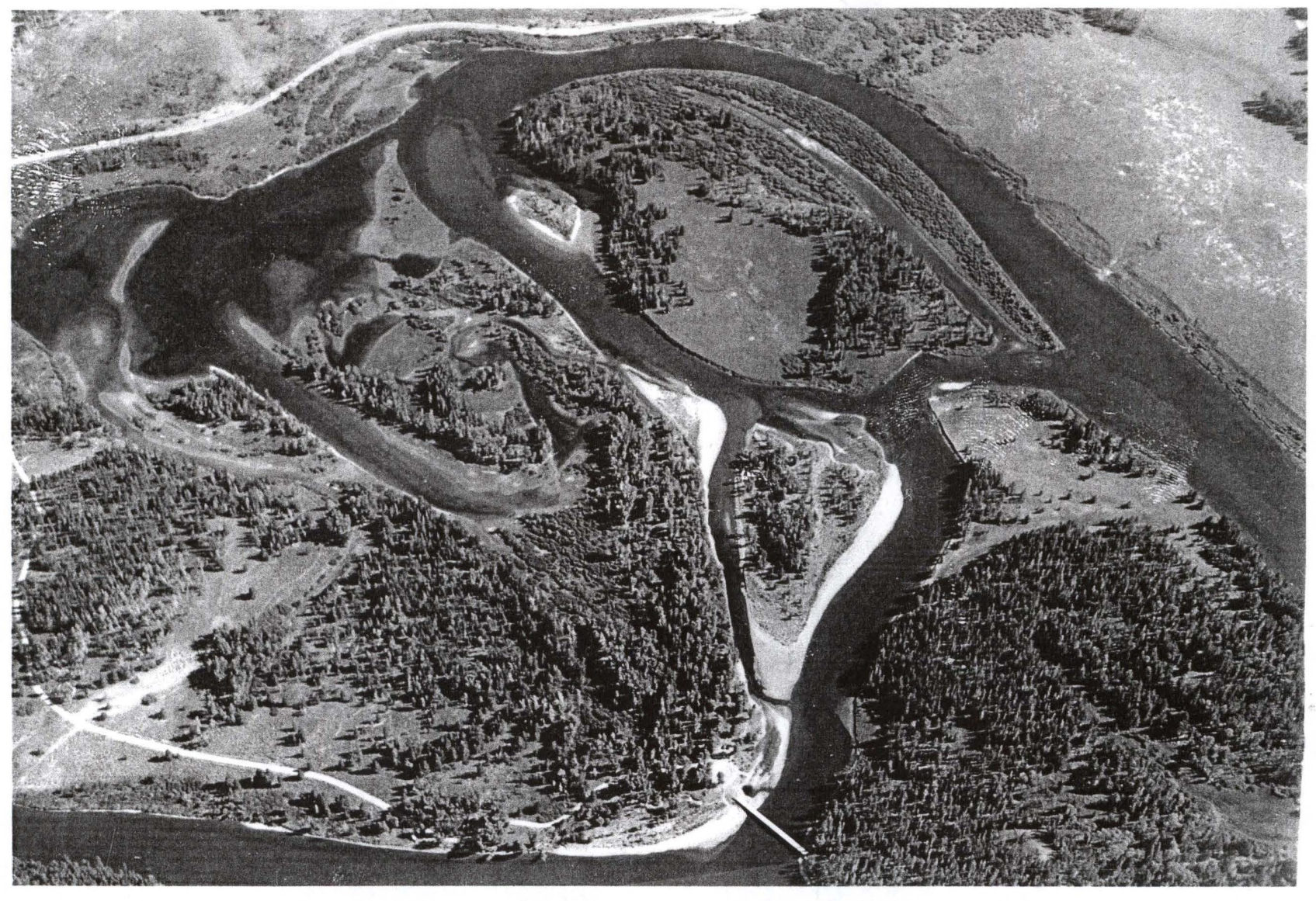

Figure 1. The Oxbow Bend of the Snake River. This was the site of intensive observations of activity patterns. 


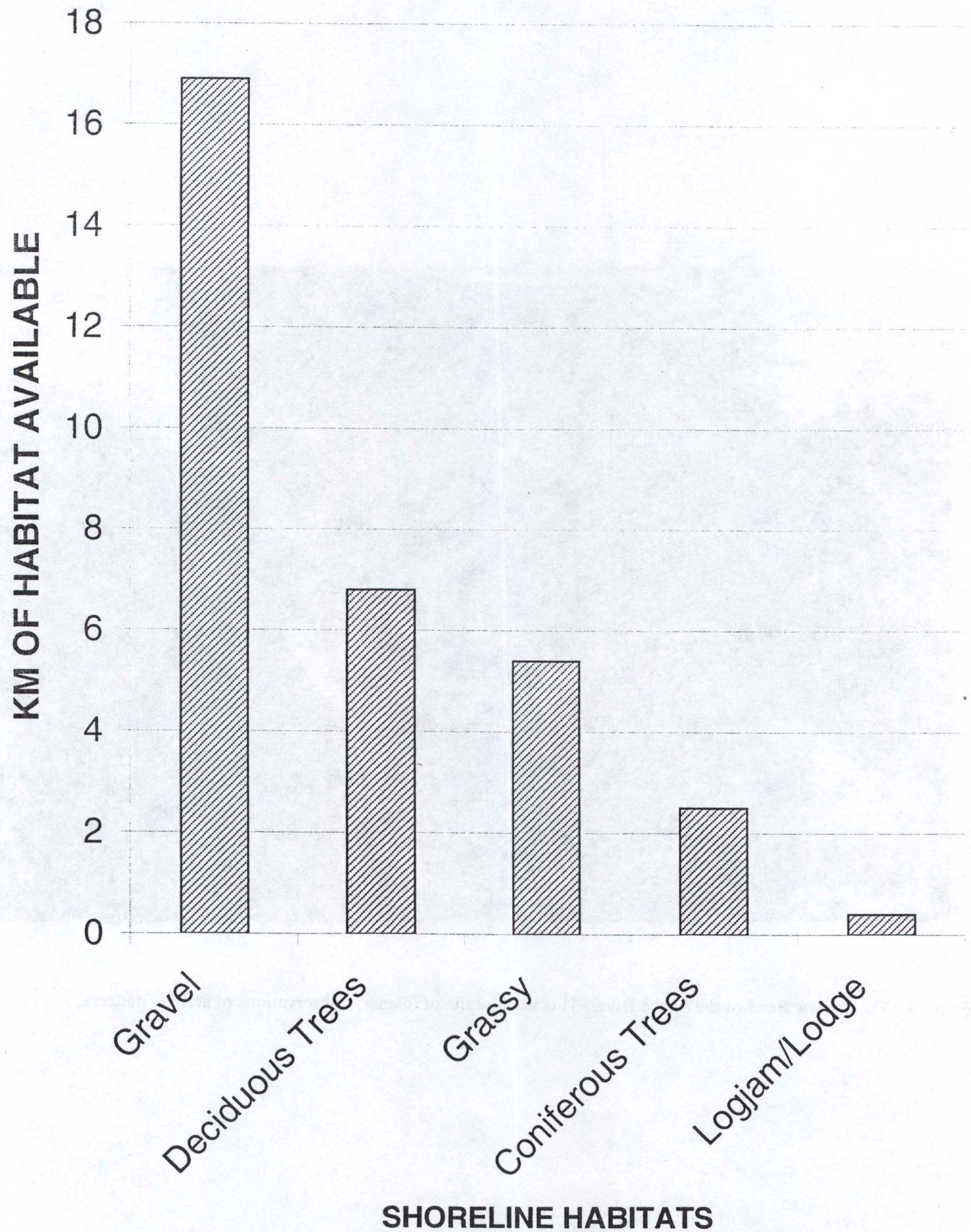

Figure 2. Availability of shoreline habitat classes along $16 \mathrm{~km}$ of the Snake River from Pacific Creek to Deadman' $\mathrm{s}$ Bar. 


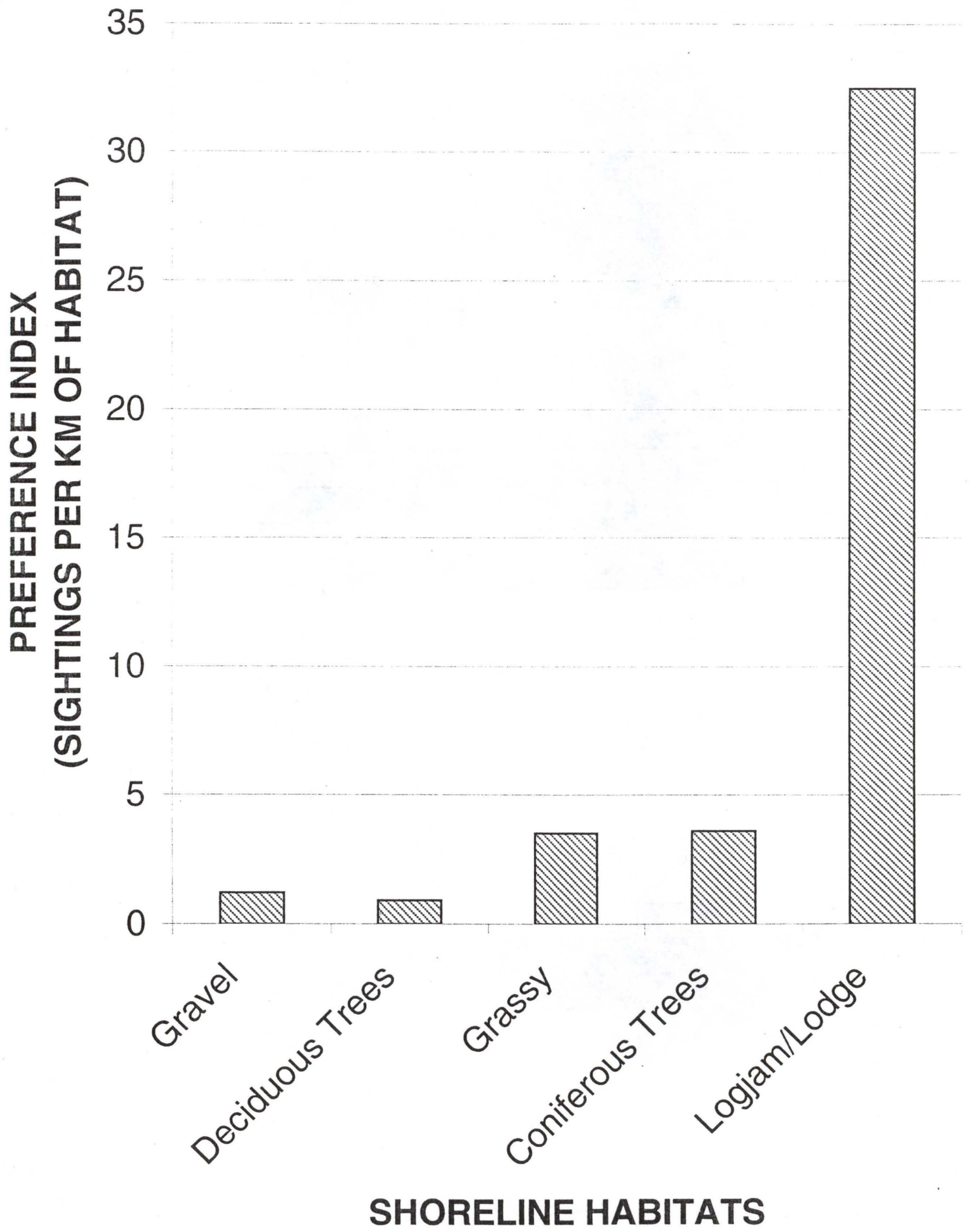

Figure 3. Relative preferences for the 5 habitat classes on the S nake River, based on 67 sightings. Each index value is calculated by dividing number of sightings by $\mathrm{km}$ of habitat available. 


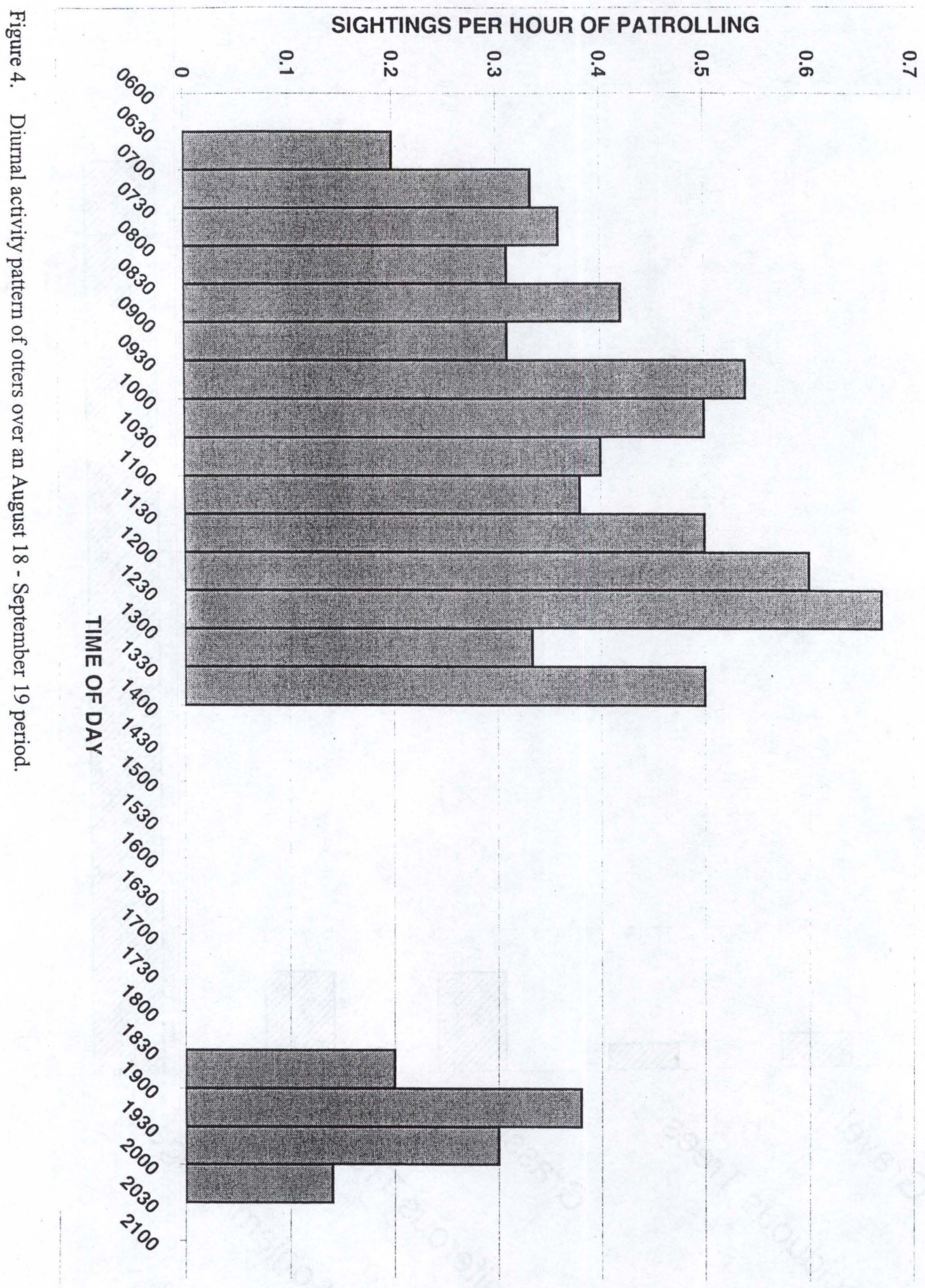




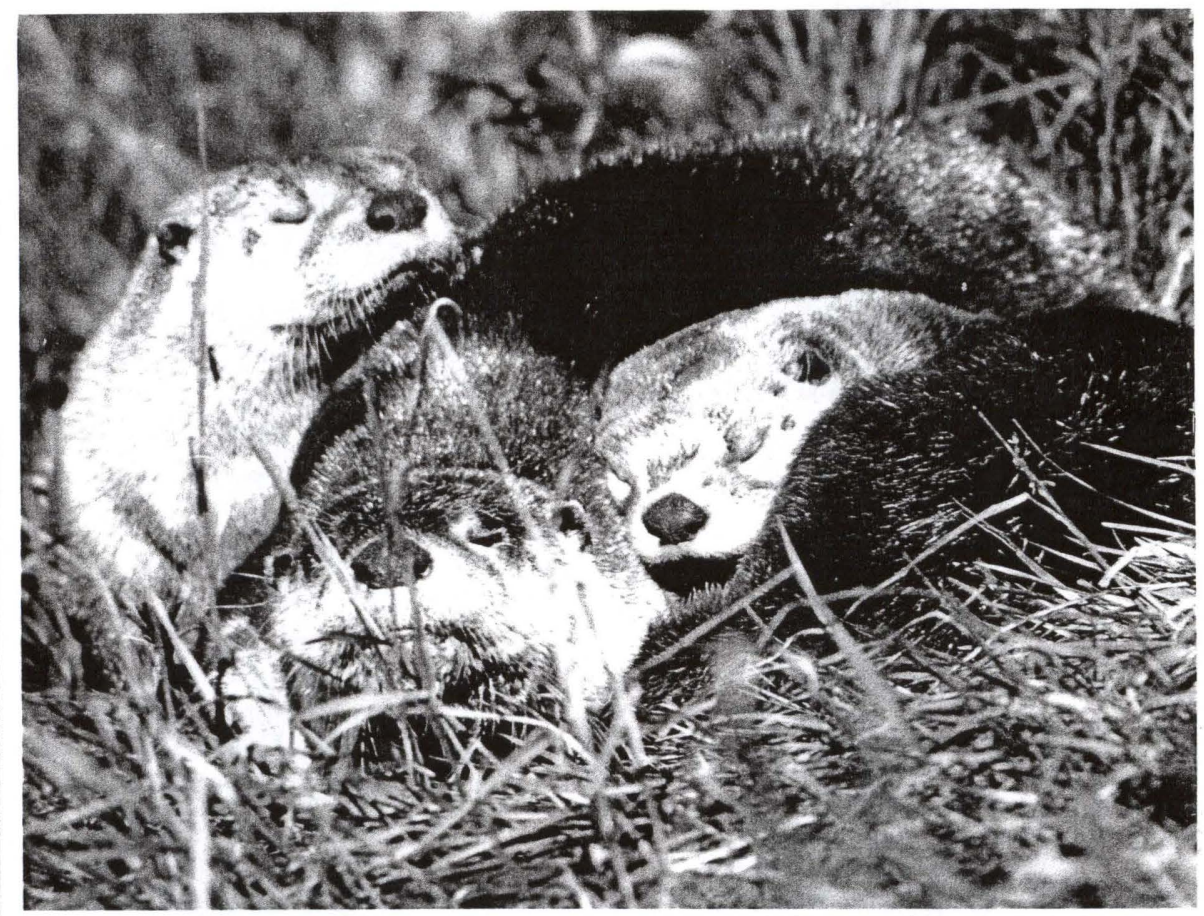

Figure 5. Habituation in otters. Eyes closed while resting in a typical "body heap" formation, these 3 otters appear to be completely at ease. They allowed observers in the canoe to approach to within $3 \mathrm{~m}$. 